\title{
Analisa Jangkauan Pemadam Kebakaran Menggunakan Sistem Informasi Geografis
}

\author{
Husmul Beze* \\ Teknologi Rekayasa Perangkat \\ Lunak, Politeknik Pertanian Negeri \\ Samarinda, Samarinda, 75131 \\ husmul@politanisamarinda.ac.id \\ *Corresponding author
}

\author{
Yulianto \\ Teknologi Rekayasa Perangkat \\ Lunak, Politeknik Pertanian Negeri \\ Samarinda, Samarinda, 75131. \\ yulianto.tile@yahoo.com
}

\author{
Hamka \\ Teknologi Hasil Perkebunan, \\ Politeknik Pertanian Negeri \\ Samarinda, Samarinda, 75131 \\ hamkanurkaya@gmail.com
}

\begin{abstract}
Abstrak-Pengerahan unit pemadam kebakaran masih dianggap cara paling efektif untuk menanggulangi musibah kebakaran di Samarinda. Oleh sebab itu perlu dilakukan analisa jangkauan unit pemadam ini secara spasial menggunakan sistem informasi geografis. Untuk diketahui seberapa luas liputan layanan yang bisa ditangani. Dalam penelitian ini dilakukan studi kasus analisa di dua kelurahan yaitu Kelurahan Baqa dan Kelurahan Tenun. Berdasarkan hasil analisa ternyata liputan layanan Unit Pemadam Kebakaran di Kelurahan Baqa dan Tenun baik yaitu menjangkau 91 persen area pemukiman penduduk.
\end{abstract}

Kata Kunci - SIG, penangulangan kebakaran, samarinda.

\section{Pendahuluan}

Bahaya kebakaran bisa terjadi setiap saat karena banyak peluang yang dapat memicu terjadinya kebakaran. Ada tiga unsur segitiga api penyebab kebakaran yaitu bahan yang mudah terbakar, ketersediaan oksigen dan suhu yang tinggi. Menurut data bahwa Kelurahan Baqa dan Kelurahan Tenun memiliki jumlah rumah semi permanen dan tidak permanen yang cukup banyak. Perumahan semi permanen dan tidak permanen terbuat dari kayu. Perumahan kelompok ini sangat disukai oleh api karena mudah terbakar. Selain itu, sebagai daerah yang memiliki dua musim, Kelurahan Baqa juga memiliki musim panas atau kemarau. Pada musim panas (kemarau) temperatur udara meningkat mencapai $36^{\circ}$ celcius. Dengan suhu yang cukup tinggi ini menjadikan Kelurahan Baqa memiliki daerah kering pada kurun waktu tertentu yaitu saat musim kemarau. Hal ini menjadi salah satu sebab kelurahan ini sangat rentan tertimpa musibah kebakaran. Apalagi jaringan listrik yang menjadi penyebab utama musibah kebakaran terlihat semrawut di beberapa kawasan.

Kelurahan Baqa dan Kelurahan Tenun ini adalah kelurahan dengan kepadatan penduduk tinggi di Samarinda. Sebagian besar rumah di kelurahan ini terbuat dari bahan tidak permanen dan semi permanen, yaitu rumah yang seluruhnya terbuat dari bahan kayu atau campuran dari kayu dan semen. Menurut data Badan Penanggulangan Bencana dan Kebakaran Samarinda, dalam dua tahun terakhir di Kecamatan Samarinda
Seberang telah terjadi musibah kebakaran sebanyak 20 kali, yaitu tahun 2017 sebanyak 11 kali dan tahun 2018 sebanyak 9 kali.

Upaya penanggulangan kebakaran yang dilakukan Badan Penanggulangan Bencana Daerah (BPBD) Kota Samarinda terhadap bahaya kebakaran mengandalkan pemadaman menggunakan mobilitas unit pemadam kebakaran. Efektivitas jangkauan siram merupakan proses paling penting dalam penanggulangan awal musibah kebakaran. Yaitu seberapa jauh kemampuan alat pemadam menjangkau lokasi kebakaran. Sebab sampai sejauh ini jaringan hidran masih sangat minim di kawasan pemukiman penduduk. Di sisi lain, hampir semua rumah penduduk di Kelurahan Baqa dan Kelurahan Tenun tidak memiliki alat pemadam ringan. Sementara itu jaringan jalan di kelurahan-kelurahan ini sebagian besar didominasi oleh gang kecil yang kurang dari 3 meter. Padahal, kondisi ideal sarana jalan untuk memperlancar proses penanggulangan kebakaran adalah lebar jalan 3 meter. Melihat kondisi ini perlu analisa jangkauan unit pemadam kebakaran di Kelurahan Baqa dan Kelurahan Tenun dengan metode spasial.

Tujuan dari penelitian ini antara lain memetakan jangkauan unit pemadam kebakaran di pemukiman penduduk Kelurahan Baqa dan Kelurahan Tenun. Di diharapkan penelitian ini bisa memberikan masukan bagi masyarakat dan Pemerintah Kota Samarinda tentang sejauh mana kemampuan unit pemadam kebakaran yang di miliki dalam menjangkau wilayah.

\section{METODOLOGI}

Untuk mempermudah proses penelitian maka penelitian ini dilakukan dengan metode waterfall. Yaitu mulai dari studi literatur hingga dokumentasi hasil penelitian.

\section{A. Studi Literatur}

Pada tahap ini dilakukan studi literatur tentang fasilitas-fasilitas pendukung yang diperlukan dalam penanggulangan kebakaran .

\section{B. Identifikasi Masalah}

Pada tahap ini dilakukan proses identifikasi terhadap cara penanggulangan kebakaran di Kelurahan Baqa dan Kelurahan Tenun. Sebagian besar cara penanggulangan kebakaran di kelurahan ini dilakukan dengan cara 
pemadaman menggunakan unit mobil pemadam kebakaran. Selain itu dilakukan juga identifikasi data-data yang diperlukan untuk penelitian, cara pengambilan data dan metode analisa yang akan digunakan dalam penelitian

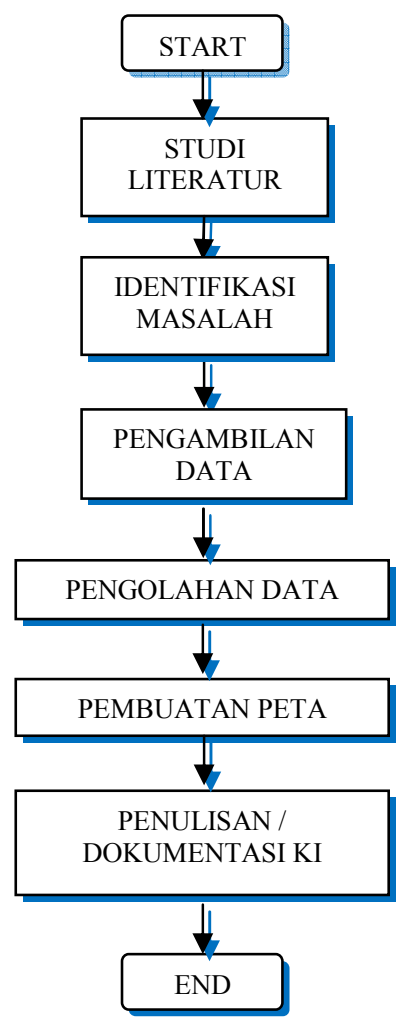

Gambar 1. Diagram Alir Penelitian

\section{Pengambilan Data}

Data yang dimaksud dalam hal ini adalah data primer. Pengambilan data dilakukan langsung di lapangan dengan menggunakan alat GPS garmin.
Data yang diambil di lapangan dalam kegiatan penelitian ini adalah mengambil titik koordinat yang merupakan point dan data atributnya. Data-data yang diambil dalam penelitian ini adalah :

1) Data Posisi puskesmas/ Rumah sakit. Data yang diambil adalah data titik koordinat puskesmas yang satu titik didepan pintu masuk bangunan.

2) Data posisi pos polisi. Data yang diambil adalah data titik koordinat pos polisi yang satu titik didepan pintu masuk bangunan.

3) Data posisi Balakar. Data yang diambil adalah data titik koordinat Balakar yang satu titik didepan pintu masuk bangunan.

4) Data kondisi dan lebar jalan dan gang.

a) Data lebar jalan dan gang diambil menggunakan meteran pada salah satu bagian tengah jalan/gang.

b) Data kondisi jalan/gang dalam penelitian ini diambil dengan cara melihat kondisi kerusakan jalan/gang. Bila jalan dan gang banyak memiliki lubang maka jalan/gang dianggap rusak.

5) Data posisi hidran air.

6) Data pemukiman penduduk. Data pemukiman penduduk diambil dari hasil dijitasi dari citra beresolusi tinggi Quick Bird. Data ini masih

D. Pengolahan Data

Data diolah dengan menggunakan analisa spasial. Khususnya tentang jangkauan siram unit layanan kebakarannya. Data yang digunakan dalam penelitian ini antara lain data koordinat pos polisi, puskesmas, balakar, dan hidran air serta data atribut nama jalan dan lebar jalan dan data batas administrasi Kelurahan Baqa dan Kelurahan Tenun, data jalan, citra quick bird dan data pemukiman penduduk. Lebih jelas mengenai proses pengolahan data dalam penelitian ini bisa dilihat pada diagram alir di bawah ini :

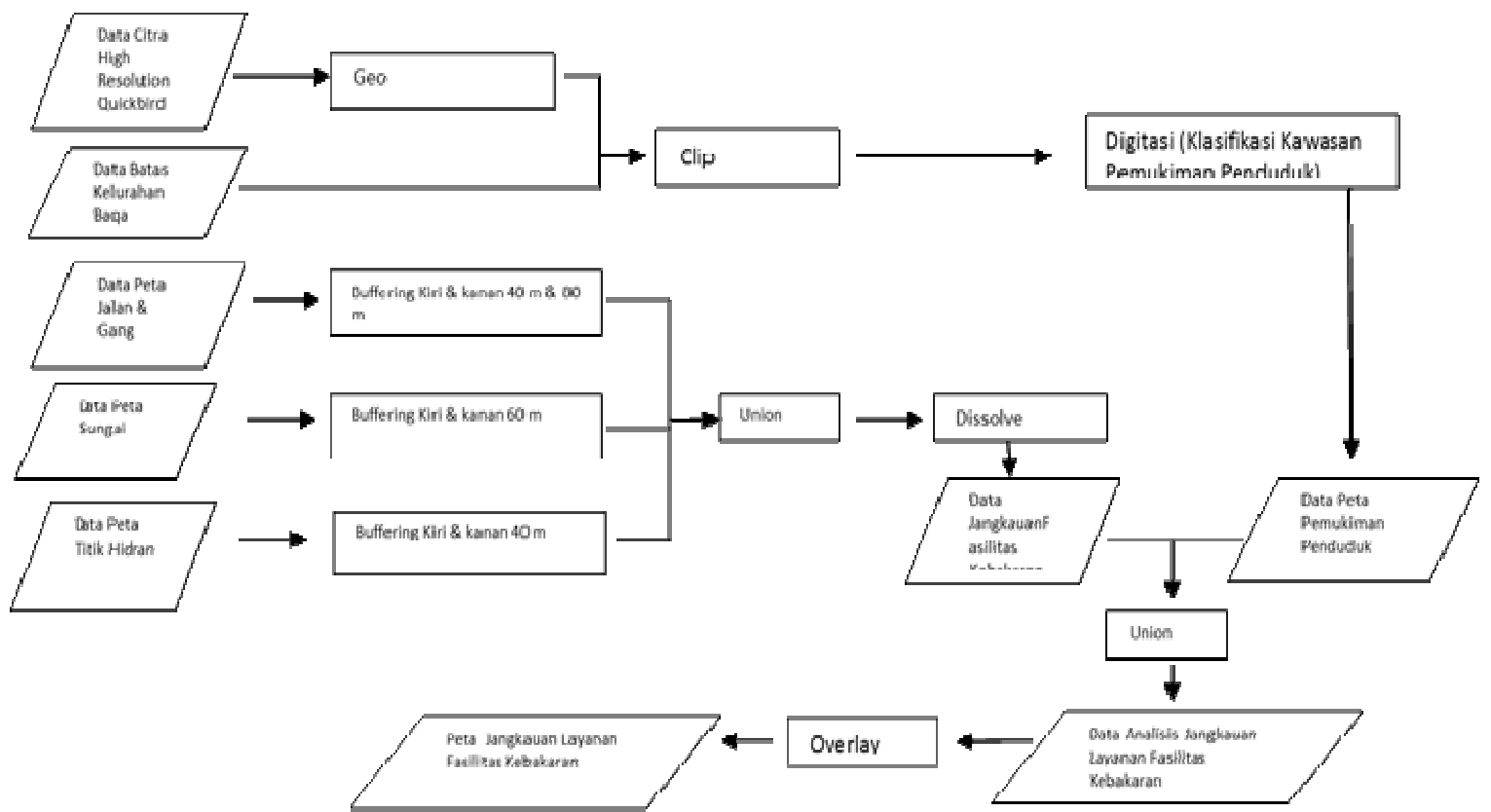

Gambar 2. Diagram Alir Pengolahan Data 
E. Pembuatan Peta

Pada tahap ini dilakukan proses layout terhadap semua data yang telah diolah pada perangkat lunak ArcGis..

\section{F. Penulisan / Dokumentasi}

Pada tahap ini dilakukan proses penulisan dengan format penulisan yang telah dilakukan sebagai keluaran dari penelitian.

\section{HASIL DAN PEMBAHASAN}

a. Hasil Penelitian

1) Fasilitas penanggulangan kebakaran

Berdasarkan hasil penelitian, ada lima fasilitas penanggulangan kebakaran di Kelurahan Baqa dan Kelurahan Tenun yang berhasil diidentifikasi yaitu sarana jalan, sumber air, fasilitas kesehatan, fasilitas keamanan dan unit pemadam kebakaran. Namun kondisi fasilitas tersebut ada yang masih bagus namun beberapa ada juga yang mengalami kerusakan, seperti jalan yang banyak berlubang, aspal gang yang sudah rusak atau gang dari kayu yang sudah berlubang akibat kayunya patah dan pakunya sudah tidak berfungsi maksimal lagi.

Fasilitas jalan dan gang di Kelurahan Baqa ini sebagian besar sudah diaspal dan disemen. Namun masih ada beberapa gang tanah dan kayu. Hal ini bisa dilihat pada Tabel 1 di bawah ini.

Tabel 1. Tabel Kondisi Jalan dan Gang di Kelurahan Baqa dan Kelurahan Tenun

\begin{tabular}{|c|c|c|c|c|}
\hline No & $\begin{array}{c}\text { Jalan/ } \\
\text { Gang }\end{array}$ & Jml & $\begin{array}{c}\text { Aspal / } \\
\text { Semen / } \\
\text { Tanah / Kayu }\end{array}$ & Kondisi \\
\hline \multirow{4}{*}{1} & \multirow{4}{*}{ Jalan } & 1 & Aspal & Bagus \\
\hline & & 4 & Aspal & Tidak Bagus \\
\hline & & 3 & Semen & Bagus \\
\hline & & 4 & Semen & Tidak Bagus \\
\hline \multirow{8}{*}{2} & \multirow{8}{*}{ Gang } & 1 & Aspal & Bagus \\
\hline & & 2 & Aspal & Tidak Bagus \\
\hline & & 53 & Semen & Bagus \\
\hline & & 13 & Semen & Tidak bagus \\
\hline & & - & Tanah & Bagus \\
\hline & & 27 & Tanah & Tidak Bagus \\
\hline & & 6 & Kayu & Bagus \\
\hline & & - & Kayu & Tidak Bagus \\
\hline
\end{tabular}

Gang di Kelurahan Baqa dan Kelurahan Tenun yang memiliki lebar lebih dari 3 meter lebih sedikit dibanding dengan gang yang memiliki ukuran lebar kurang dari 3 meter. Identifikasi lebar jalan dan gang ini penting dilakukan. Alasannya gang dengan lebar lebih dari 3 meter memudahkan unit mobil pemadam kebakaran melewatinya.
Tabel 2. Tabel Gang di Kelurahan Baqa dan Kelurahan Tenun

\begin{tabular}{|c|c|c|}
\hline No & Gang & Jumlah \\
\hline 1 & $\begin{array}{c}\text { Gang yang bisa dilewati mobil } \\
\text { pemadam kebakaran }\end{array}$ & 33 \\
\hline 2 & $\begin{array}{c}\text { Gang yang tidak bisa dilewati } \\
\text { mobil pemadam kebakaran }\end{array}$ & 69 \\
\hline
\end{tabular}

Selain sarana jalan, fasilitas sumber air penting diidentifikasi. fasilitas sumber air yang ada di Kelurahan Baqa dan Kelurahan Tenun ada dua jenis yaitu hidran air dan sungai. Hidran air penunjang penanggulangan kebakaran di Kelurahan Baqa dan Kelurahan Tenun ada 3. Namun setelah di lakukan survei hanya terdapat 1 hidran air yang berada di Jalan Sutra Kembang. Di Kelurahan Baqa dan Tenun terdapat dua sungai yang bisa digunakan sebagai sumber air yaitu Sungai Mahakam, Sungai Baqa dan Sungai Baqa Kecil. Selain itu Kelurahan Baqa juga memiliki satuan penanggulangan bahaya kebakaran (balakar) yaitu di Jalan Sultan Hasanuddin dan balakarcana milik Kelurahan Baqa yang berada di Jalan HOS Cokroaminoto. Fasilitas lain yang dimiliki untuk mengantisipasi musibah kebakaran adalah sarana kesehatan yaitu Puskesmas Baqa di J1 Daeng Mangkona.

Selain keempat fasilitas di atas, ada satu fasilitas lagi yang harus dimiliki kelurahan untuk penanggulangan bencana kebakaran yaitu satuan pengamanan. Namun sejauh ini Kelurahan Baqa dan Kelurahan Tenun tidak memiliki fasilitas keamanan. Hanya terdapat pos polisi dan satuan Brimob terdekat yaitu di Kelurahan Rapak Dalam yang berada di Jalan Sultan Hasanuddin.

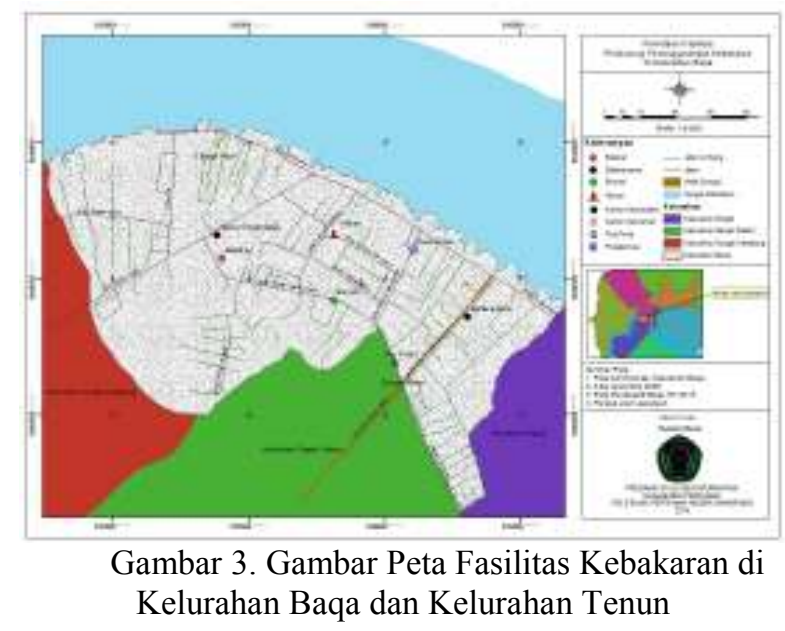

2) Pemukiman Penduduk

Kelurahan Baqa dan Kelurahan Tenun memiliki luas sekitar 133,29 Ha. Menurut hasil analisa menggunakan citra satelit Quick Bird dengan resolusi 0,4 meter, sekitar 66,64 persen lahan di Kelurahan Baqa dan Kelurahan Tenun sudah berupa perumahan penduduk atau 89,1 Ha. Selebihnya adalah lahan terbuka, semak dan perairan. Hasil pengamatan menunjukkan bahwa sebagian besar 
rumah di kelurahan ini terbuat dari kayu atau bahan semi permanen.

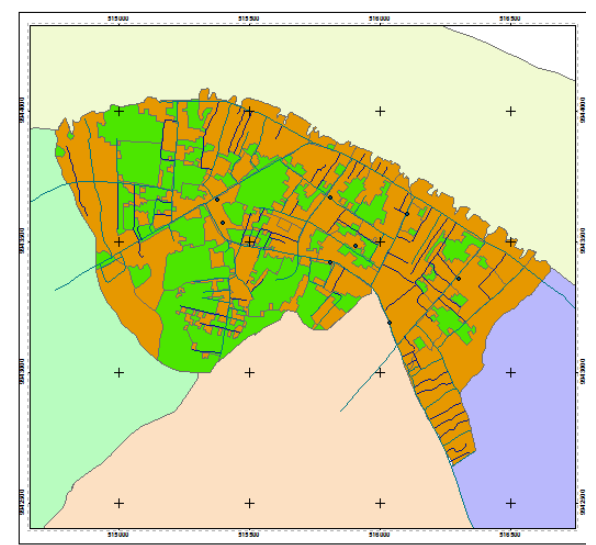

Gambar 4. Gambar Peta Kawasan Pemukiman Pendidikan Kelurahan Baqa

b. Pembahasan

Menurut Nisfi dkk jalan memegang peranan penting dalam kegiatan transportasi dan mobilitas penduduk. Dalam proses musibah kebakaran. Kualitas jalan dan lebar jalan adalah salah satu variabel sarana dan prasarana penting dalam proses penanggulangan kebakaran. Di Kelurahan Baqa dan Kelurahan Tenun terdapat 2 jenis jalan yaitu aspal dan semen. Tujuh dari duabelas jalan di Kelurahan Baqa dan Kelurahan Tenun dalam keadaan rusak. Jalan-jalan tersebut yaitu Jalan Sultan Hasanuddin, Jalan Patimura, Jalan Lamadukeleng, Jalan Padaelo, Jalan Sutra Murni, Jalan Padat Karya dan Sutra Kembang. Sementara jalan yang dalam kondisi baik yaitu Jalan Bung Tomo, Jalan Daeng Mangkona, Jalan Pangeran Bendahara, Jalan PU dan Jalan HOS Cokroaminoto. Seluruh jalan yang ada di kelurahan ini memiliki lebar lebih dari 3 meter. Sehingga cukup representatif digunakan sebagai jalur transportasi untuk lalu lintas mobil pemadam kebakaran dan evakuasi korban kebakaran.

Selain jalan, di kelurahan ini juga banyak terdapat gang. Gang yang terdapat di kelurahan ini ada 4 jenis yaitu aspal, semen, tanah dan kayu. Gang di Kelurahan Baqa dan Tenun sebagian besar sudah disemenisasi. Namun tidak semua gang tersebut bisa dilalui kendaraan roda empat. Berdasarkan inventarisasi saat penelitian ada 69 gang yang tidak bisa dilewati oleh mobil pemadam kebakaran. Gang-gang tersebut menyebar di seluruh Kelurahan Baqa dan Kelurahan Tenun. Gang yang memiliki lebar kurang dari 3 meter ini tidak bisa digunakan untuk sarana pendukung penanggulangan kebakaran saat musibah terjadi, gang tersebut antara lain: Gang Mawar 1, Gang Annisa, Gang Kurnia, Gang Vera, Gang Wardah, Gang Sosial, Gang Nangka, Gang Cempaka, Gang Rahmat dan lain-lain. Sementara jumlah gang yang representatif bisa dilewati mobil pemadam kebakaran berjumlah 33 gang diantaranya Gang Ridho, Gang Tani, Gang Iklas, Gang Murni, Gang Datu, Gang Langgar, Gang Syukur, Gang Karya Putra dan lain-lain.

Kondisi gang di Kelurahan Baqa dan Kelurahan Tenun hanya sebagian kecil yang rusak. Hanya 42 gang dari 102 gang yang ada di kelurahan ini kondisinya rusak diantaranya Gang Tani, Gang Iklas, Gang Citra 2, Gang
Annisa, Gang Sosial, Blok C Gang Langgar, Gang Ismail Amir, Gang HM Senang, Gang Syukur dan lain-lain. kerusakan yang terjadi berupa lubang yang tersebar di sebagian besar gang. Kerusakan ini akibat umur semen gang di atas 5 tahun. Namun kerusakan gang tersebut tidak mempengaruhi akses mobil kebakaran untuk masuk sebab kerusakannya tidak parah.

Fasilitas sumber air menjadi masalah di kelurahan ini. Sumber air ada dua kategori. yaitu sumber air dari alam dan sumber air buatan. Sumber air alam berupa sungai dan sumber air buatan berupa hidran. Ada dua sungai yang melintasi yaitu Sungai Mahakam dan Sungai Baqa. Menurut hasil pengamatan Sungai Mahakam selalu berisi air bahkan ketika kemarau datang. Sungai Mahakam terletak di sebelah utara. Sungai Rapak Dalam membelah Kelurahan Baqa, tepatnya di samping J1 HOS Cokroaminoto. Tapi Sungai Rapak Dalam iniakan kering kala kemarau. Padahal ancaman kebakaran sangat besar kala musim kemarau.

Mengenai hidran, menurut data inventaris terdapat 3 hidran air yaitu di J1 Sultan Hasanuddin, J1 Sutra Kembang dan Jl Bung Tomo. Namun menurut hasil survei ternyata hanya ada satu hidran yang terlihat yaitu di Jl Sutra Kembang. Sampai saat ini belum diperoleh informasi mengenai dua hidran yang hilang tersebut. Masalah lain yang dihadapi Kelurahan Baqa adalah minimnya aparat keamanan dalam mengamankan kawasan saat musibah kebakaran terjadi. Khususnya mengamankan arus lalu lintas dan harta benda korban kebakaran. Padahal di dekat dekat wilayah kelurahan ini terdapat Kantor Polsek Samarinda Seberang.

Dalam musibah kebakaran Balakar sangat berperan penting dalam suatu kebakaran. Di Kelurahan Baqa terdapat satu buah Balakar, yang terletak di Jalan Sultan Hasanuddin. Balakar tersebut memiliki 4 unit mobil yang teridiri dari 1 unit mobil komando dan 3 unit mobil tangki. Sedangkan Balakarcana yang terletak di Jalan HOS Cokroaminoto memiliki 2 mesin penyemprot. Untuk analisa spasialnya, jangkauan siram unit pemadam kebakaran sangat bagus. Menurut hasil analisa 80,99 Нa atau sekitar 91 persen kawasan pemukiman di Kelurahan Baqa dan Kelurahan Tenun masuk dalam jangkauan siram unit pemadam kebakaran. Sementara luas Kelurahan Baqa dan Kelurahan Tenun sekitar 133,29 Ha dan yang menjadi areal pemukiman adalah sekitar 89,06 Ha.

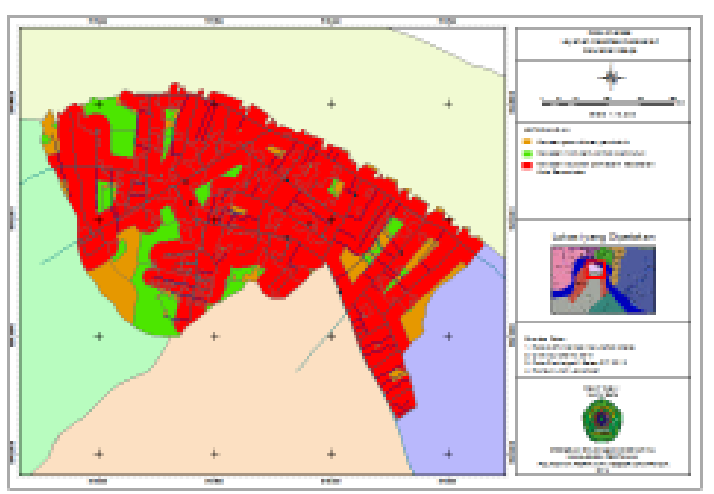

Gambar 5. Gambar Peta Analisa Jangkauan Siram Layanan Unit Pemadam Kebakaran 


\section{KESIMPULAN}

Secara spasial jangkauan siram layanan unit pemadam kebakaran di Kelurahan Baqa dan Kelurahan Tenun sangat baik yaitu sudah menjangkau 91 persen dari luas pemukiman penduduk. Namun perlu dilakukan penambahan sumber air buatan di beberapa titik yang dianggap rawan terjadi musibah kebakaran untuk mempercepat proses pemadaman.

\section{DAFTAR PUSTAKA}

Lestanto, Yusuf. 2012. Journal of Computer and Information,

$1(1)$ http://garuda.ristekbrin.go.id/documents/detail/13935 3.

Nurtata, Arimudin. 2016. Pengaruh Penataan Bangunan dan Lingkungan Terhadap Resiko Bencana
Kebakaran Di Kelurahan Nyamplungan Kota Surabaya. Jurnal Teknik ITS, 5(2), 2337-3539, http:/ejurnal.its.ac.id/index.php/teknik/article/view/1 $8876 / 3242$,

Nisfi, S. and Dkk. 2008. Identifikasi kawasan rawan kebakaran. Universitas Lambung Mangkurat.

Raehanayati, 2012. Kesiapsiagaan Menghadapi Bencana Kebakaran Gedung Graha Sainta (Gs) Lantai Ii Universitas Brawijaya Menggunakan Metode Campus Watching, 1(1), 2302-9021. https://erudio.ub.ac.id/index.php/erudio/article/view/1 07/97.

Saraswati, Dinimiar Fitrah dan Cahyono, Agung Budi. 2017. Analisis Daerah Risiko Bencana Kebakaran di Kota Surabaya dengan Menggunakan Sistem Informasi Geografis. Jurnal Teknik ITS, 6 (2), 23373539 , http://ejurnal.its.ac.id/index.php/teknik/article/view/2 $4410 / 4795$ 